OSEANOLOGI DAN LIMNOLOGI DI INDONESIA

Online ISSN: 2477-328X

Akreditasi RISTEKDIKTI No. 21/E/KPT/2018

http://jurnal-oldi.or.id

\title{
Karakteristik Fisika dan Kimia Perairan di Laut Jawa - Ambang Dewakang
}

\author{
Hanny Meirinawati dan M. Riza Iskandar
}

Pusat Penelitian Oseanografi - LIPI

hanny.meirinawati@gmail.com; ririzaiskandar@gmail.com

Submitted 20 March 2017. Reviewed 25 September 2017. Accepted 4 February 2019.

DOI: 10.14203/oldi.2019.v4i1.140

\begin{abstract}
Abstrak
Laut Jawa merupakan daerah penghasil ikan pelagis di Indonesia. Kelimpahan dan distribusi ikan ini dipengaruhi oleh karakteristik fisika dan kimia perairan laut. Sifat kimia penting yang mempengaruhi kelimpahan ikan yaitu ketersediaan nutrien. Nutrien merupakan senyawa dasar dari siklus biogeokimia laut yang berperan penting dalam meningkatkan produktivitas perairan melalui peningkatan pertumbuhan fitoplankton. Tujuan dari penelitian ini adalah untuk mengetahui kondisi terkini dari karakteristik sifat fisikakimia perairan di Laut Jawa sampai Ambang Dewakang. Penelitian dilakukan pada bulan November 2014 dengan parameter fisika (suhu, salinitas, turbiditas, densitas) dan parameter kimia yaitu nutrien ( $\mathrm{DIN}, \mathrm{PO}_{4}-\mathrm{P}$, $\mathrm{SiO}_{3}-\mathrm{Si}$ ), pH, dan DO pada tujuh stasiun di Laut Jawa sampai dengan Ambang Dewakang. CTD (ConductivityTemperature-Depth) SBE (Sea Bird Electronics) 911 Plus digunakan untuk mengukur sifat fisika perairan. Sampel air diambil menggunakan Rosette sampler, sedangkan analisis kandungan nutrient merujuk pada Strickland and Parsons 1972. Hasil penelitian memperlihatkan bahwa suhu perairan di Laut Jawa berkisar antara $13,06-30,33{ }^{\circ} \mathrm{C}$ dengan rerata $25,29{ }^{\circ} \mathrm{C}$ sedangkan salinitas berkisar $33,07-34,74$ psu dengan rerata 34,41 psu. Variasi suhu dan salinitas menunjukkan kondisi homogen karena pengaruh proses mixing. Konsentrasi DIN $\left(\mathrm{NO}_{3}-\mathrm{N}+\mathrm{NO}_{2}-\mathrm{N}+\mathrm{NH}_{4}-\mathrm{N}\right), \mathrm{PO}_{4}-\mathrm{P}, \mathrm{SiO}_{3}-\mathrm{Si}$ berturut-turut adalah sebagai berikut $0,070-$ $0,180 \mathrm{mg} / \mathrm{L}, 0,004-0,022 \mathrm{mg} / \mathrm{L}, 0,082-0,361 \mathrm{mg} / \mathrm{L}$ dengan reratanya masing-masing $0,096 \mathrm{mg} / \mathrm{L}, 0,159$ $\mathrm{mg} / \mathrm{L}, 0,010 \mathrm{mg} / \mathrm{L}$. Rasio DIN/DIP sebesar 13,24, menunjukkan bahwa kualitas perairan laut Jawa berada pada kategori moderate (sedang).
\end{abstract}

Kata kunci: Laut Jawa, nutrien, salinitas, $\mathrm{pH}$, dan suhu

\begin{abstract}
Physical and Chemical Properties of Waters in Java - Ambang Dewakang Sea. The Java Sea is a region of important pelagic fish production in Indonesia. The distribution of abundance of fish is affected by changes in water physical and chemical properties. The important chemical property that can affect the abundance of the fish is the availability of nutrients. Nutrients are the basic compounds of marine biogeochemical cycles that play important role in increasing aquatic productivity through growth of the phytoplankton. The purposes of this study are to know recent condition of chemical and physical characteristics of the sea water within the region Java Sea - Ambang Dewakang and to investigate relationships among these parameters. This research was conducted in November 2014 at 7 stations in the region. The observed parameters were physical (temperature, salinity, turbidity, density) and chemical such as nutrients (DIN, $\mathrm{PO}_{4-}$ $\mathrm{P}, \mathrm{SiO}_{3}-\mathrm{Si}$ ), $\mathrm{pH}$, and DO. CTD (Conductivity-Temperature-Depth) SBE (Sea Bird Electronics) 911 Plus was used to measure water physical properties. Water sample was collected using Rosette sampler, while analysis of nutrients concentration employed methods from Strickland and Parsons 1972. The result showed that temperatures in the Java Sea ranged from $13.06-30.33{ }^{\circ} \mathrm{C}$ with an average of $25.29{ }^{\circ} \mathrm{C}$, whereas salinity
\end{abstract}


ranged between $33.07-34.74$ psu with an average of 34.41 psu. Variations within temperature and salinity showed a homogeneous condition due to the influence of mixing processes. Concentration range of $\mathrm{DIN}\left(\mathrm{NO}_{3}-\right.$ $\left.\mathrm{N}+\mathrm{NO}_{2}-\mathrm{N}+\mathrm{NH}_{4}-\mathrm{N}\right), \mathrm{PO}_{4}-\mathrm{P}, \mathrm{SiO}_{3}-\mathrm{Si}$ were from 0.070 to $0.180 \mathrm{mg} / \mathrm{L}$, from 0.004 to $0.022 \mathrm{mg} / \mathrm{L}$ and from 0.082 to $0.361 \mathrm{mg} / \mathrm{L}$, with an average of $0.096 \mathrm{mg} / \mathrm{L}, 0.010 \mathrm{mg} / \mathrm{L}$, and $0.159 \mathrm{mg} / \mathrm{L}$ respectively. The ratio DIN/DIP of 13.24 showed that the waters quality of Java Sea was in the moderate category.

Keywords: Java sea, nutrient, salinity, $\mathrm{pH}$, and temperature

\section{Pendahuluan}

Laut Jawa merupakan daerah penangkapan ikan pelagis yang menyumbangkan produksi perikanan cukup besar di Indonesia. Komoditas tangkapan ikan utama adalah ikan layang, selar, kembung dan tembang (Merta et al. 2004) dengan rata-rata laju penangkapan ikan sebesar 1,5-2,5 ton/ hari (Pasaribu et al. 2004). Potensi perikanan tangkap yang besar tersebut didukung oleh dinamika fisika dan kimia perairan. Perairan laut Jawa dipengaruhi oleh sistem munson yang menyebabkan pergerakan massa air dari Laut Cina Selatan yang bersuhu dingin dengan salinitas rendah dan Laut Flores (Susilo et al. 2015). Salinitas permukaan perairan Laut Jawa berkisar antara $31-34(\mathrm{psu})$ dengan salinitas minimum ditemui pada bulan Mei dan salinitas maksimum terjadi pada bulan September. Pada musim Timur (Juni - Juli) salinitas permukaan cenderung lebih tinggi di bandingkan dengan saat musim Barat (Desember - Februari), hal ini diduga adanya masukan massa air dari timur Laut Jawa (Najid et al. 2012).

Pengaruh dinamika oseanografi di Laut Jawa terhadap hasil tangkapan ikan pelagis di PPN Kejawanan telah diteliti oleh Susilo et al. (2013) pada tahun 2013. Hasil penelitian mereka menyebutkan bahwa komposisi utama hasil tangkapan terdiri atas ikan tembang, tenggiri dan alu-alu dan jumlah tangkapan berfluktuasi mengikuti musim. Musim panen ikan terjadi pada musim peralihan timur menuju ke barat (September - November), rata-rata tangkapan bulanan sebesar $417.478 \mathrm{~kg}$, dengan nilai produksi tertinggi $543.205 \mathrm{~kg}$ pada bulan November. Penangkapan ikan tertinggi terjadi pada suhu permukaan laut berkisar antara $25,74-35,00{ }^{\circ} \mathrm{C}$ dengan nilai ratarata sebesar $31,37^{\circ} \mathrm{C}$ (Susilo et al. 2015).

Faktor lain yang mempengaruhi kelimpahan ikan adalah ketersediaan nutrien di laut. Sumber utama nutrien di laut yaitu berasal dari pelapukan batu, pembusukan material organik dan limbah akibat aktivitas manusia yang terbawa aliran sungai dan masuk ke laut (Chen 2011). Distribusi dan konsentrasi nutrien dipengaruhi oleh proses biotik (produksi fitoplankton, ekresi, dan remineralisasi) dan abiotik (upwelling, sirkulasi termohalin, masukkan darat seperti dari aktivitas manusia dan udara) (Pasqueron de Fommervault et al. 2015). Nutrien merupakan material dasar siklus biogeokimia laut dan berperan penting dalam produktivitas perairan serta pertumbuhan fitoplankton (Wei et al. 2016). Unsur utama penyusun nutrien tersebut antara lain nitrogen $(\mathrm{N})$, fosfor $(\mathrm{P})$, dan silikon $(\mathrm{Si})$ yang merupakan elemen biogenik untuk pertumbuhan fitoplankton dan menentukan karateristik geokimia di laut ( $\mathrm{Li}$ et al. 2015).

Nitrogen adalah salah satu nutrien pembatas pertumbuhan organisme autotrofik seperti fitoplankton dan perifiton (USEPA 2001). Dissolved Inorganic Nitrogen (DIN) atau nitrogen anorganik terlarut terdiri dari amonia, nitrit, dan nitrat, sedangkan fosfor adalah nutrien yang juga diperlukan untuk pertumbuhan organisme dan dapat menjadi faktor pembatas bagi pertumbuhan fitoplankton. Fosfor terlarut dalam kolom air laut sebagian besar dalam bentuk ortofosfat $\left(\mathrm{PO}_{4}^{-3}\right)$, yang dapat dimanfaatkan langsung oleh fitoplankton autotrofik (USEPA 2001). Silikat terlarut pada sebuah perairan berasal dari pelapukan yang terjadi karena interaksi aktivitas tektonik, tipe batuan dasar dan dinamika iklim (Liu et al. 2011). Selain itu, organisme bercangkang seperti diatom dan radiolaria melepaskan silika terlarut yang berasal dari silika amorf terhidrasi.

Tujuan dari penelitian ini adalah untuk untuk mengetahui kondisi terbaru dari karakteristik fisika-kimia perairan serta hubungan kedua faktor tersebut di Laut Jawa-Ambang Dewakang. Hasil penelitian ini diharapkan dapat memberikan informasi dasar untuk mengetahui lingkungan Laut Jawa-Ambang Dewakang.

\section{Metodologi}

\section{Lokasi Penelitian}

Penelitian ini merupakan Joint Research Cruise LIPI-IOCAS bulan November 2014 dengan Kapal Riset Baruna Jaya VIII. Pergerakan kapal mulai dari Laut Jawa sampai perairan Ambang Dewakang yang terletak di selatan Pulau Sulawesi (Gambar 1). Dari track kapal, ditentukan tujuh stasiun pengambilan sampel (St. 1 - 7). Rosette Water Sampler digunakan untuk pengambilan 
sampel air laut pada dua kedalaman, yaitu lapisan permukaan pada kedalaman $5 \mathrm{~m}$ dan lapisan dasar yang bervariasi dari kedalaman $40 \mathrm{~m}$ hingga $90 \mathrm{~m}$. Selanjutnya air laut dimasukkan ke dalam dua botol yang berbeda yaitu: botol Winkler untuk analisis oksigen terlarut (DO) dan botol polietilen untuk analisis nutrien.

\section{Pengukuran DO}

Sampel air laut dalam botol Winkler dianalisis menggunakan metode Winkler untuk mengukur DO. Metode Winkler menggunakan prinsip titrasi yodometri dengan memanfaatkan larutan basa kuat $\mathrm{MnSO}_{4}$ untuk bereaksi dengan hidrosil $\left(\mathrm{OH}^{-}\right)$membentuk endapan $\mathrm{Mn}(\mathrm{OH})_{2}$ yang sangat labil (Hutagalung et al. 1985). Endapan $\mathrm{Mn}(\mathrm{OH})_{2}$ tersebut akan langsung bereaksi dengan oksigen terlarut dalam sampel air laut membentuk $\mathrm{Mn}(\mathrm{OH})_{3}$. Banyaknya $\mathrm{Mn}(\mathrm{OH})_{3}$ yang terbentuk tersebut ekuivalen dengan jumlah oksigen terlarut sehingga dapat diketahui kadar DO.

\section{Pengukuran Nutrien}

Sampel air dalam botol polietilen disaring menggunakan kertas saring $0,45 \mu \mathrm{m}$ untuk dianalisis nutriennya. Kandungan nutrien $\mathrm{NO}_{3}-\mathrm{N}$, $\mathrm{NO}_{2}-\mathrm{N}, \quad \mathrm{NH}_{4}-\mathrm{N}, \mathrm{PO}_{4}-\mathrm{P}$, dan $\mathrm{SiO}_{3}-\mathrm{Si}$ diukur menggunakan metode kolorimetrik (Strickland dan Parsons 1972) dengan spektrofotometer Shimadzu ${ }^{\circledR}$ UV-1800 sebagai instrumen utamanya. Prinsip reaksi kimia pembentukan warna dalam kolorimetri yang digunakan pada tiap senyawa nutrien adalah masing-masing $\mathrm{NO}_{2}-\mathrm{N}$ (DiazoAzo), $\mathrm{NO}_{3}-\mathrm{N}$ (reduksi kadmium), $\mathrm{NH}_{4}-\mathrm{N}$ (oksidasi natrium hipobromit), $\mathrm{PO}_{4}-\mathrm{P}$ (reduksi asam askorbat dari fosfor molibdenum biru), dan $\mathrm{SiO}_{3}-\mathrm{Si}$ (silika molibdenum biru).

\section{Pengukuran Parameter Fisika Perairan}

Parameter fisika perairan yang diukur adalah suhu, salinitas, densitas, turbiditas dan $\mathrm{pH}$. Pengukuran sifat fisik di atas kecuali $\mathrm{pH}$ menggunakan instrumen CTD (ConductivityTemperature-Depth) SBE (Sea Bird Electronics) 911 Plus. Pengukuran $\mathrm{pH}$ menggunakan $\mathrm{pH}$ meter dan dilakukan pada air yang diambil menggunakan Rosette Water Sampler.

\section{Analisis Data}

Data yang diolah hanya berasal dari data downcast yaitu pengukuran profil sewaktu CTD diturunkan ke kedalaman/tekanan tertentu. Pengolahan data CTD dilakukan dengan mengunakan perangkat lunak SBE Data Processing 5.37e. Data suhu dan salinitas kemudian digunakan untuk menentukan karakterisitik massa air mengunakan diagram suhu-salinitas (Diagram TS). Selain itu, diagram ini digunakan pula untuk menunjukan kondisi pencampuran dari perubahan suhu dan salinitas dalam kontur densitas tertentu. Stratifikasi kolom air dianalisis menggunakan frekuensi BruntVaisala. Frekuensi ini menggambarkan kestabilan kolom air yang dipengaruhi oleh gaya gravitasi (g) serta menggambarkan osilasi fluida secara vertikal. Frekuensi Brunt-Vaisala dihitung menggunakan persamaan,

$$
N^{2}=-\frac{g}{\rho_{o}} \frac{d \rho}{d z}
$$

$\rho 0$ merupakan rata-rata densitas kolom air, $d \rho / \mathrm{dz}$ meurpakan perubahan densitas terhadap kedalaman dan $\mathrm{g}$ merupakan percepatan gravitasi.

\section{Analisis Statistik}

Analisis statistik dilakukan dengan menggunakan software SPSS 17. Korelasi antara parameter fisika-kimia dianalisis menggunakan korelasi Pearson.

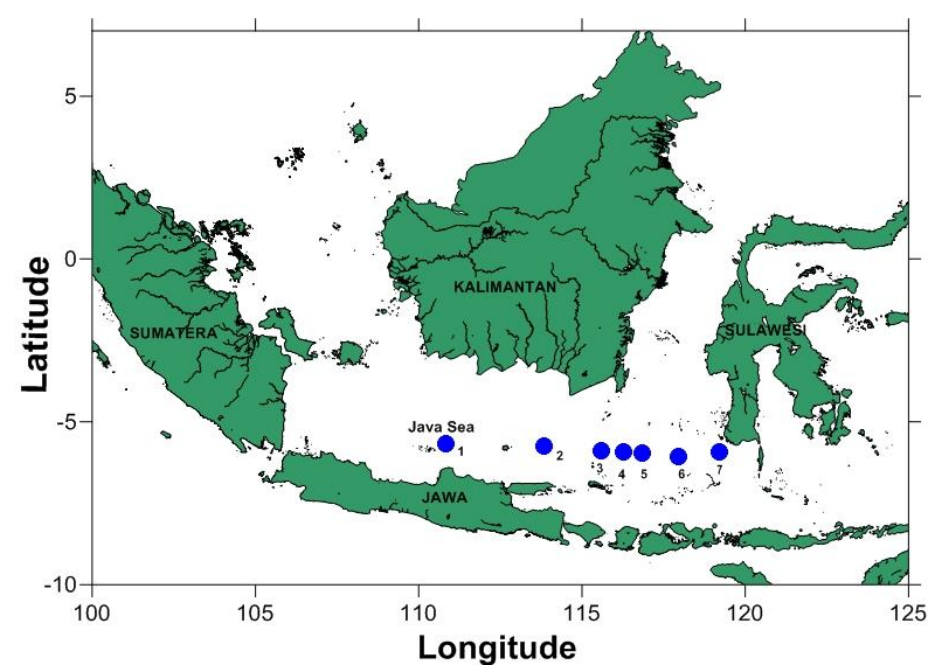

Gambar 1 . Lokasi Stasiun Penelitian di Laut Jawa-Ambang Dewakang, November 2014

Figure 1. Research Station in Java-Ambang Dewakang Sea, November 2014 


\section{Hasil}

Salinitas, suhu, $\mathrm{pH}, \mathrm{DO}$, konsentrasi $\mathrm{PO}_{4}-\mathrm{P}$, DIN, $\mathrm{SiO}_{3}$-Si di lokasi penelitian ditunjukkan pada Tabel 1. Nilai pH, DO, salinitas dan suhu tidak menunjukkan variasi yang tajam di setiap stasiun. Distribusi spasial dan vertikal $\mathrm{pH}$ berkisar antara 7,84 - 7,99 meskipun tampak adanya penurunan nilai $\mathrm{pH}$ dari lapisan atas ke lapisan bawah di semua stasiun. Kecenderungan nilai $\mathrm{pH}$ tersebut mengindikasikan bahwa lapisan bawah relatif lebih asam dibandingkan lapisan atas. DO juga menunjukkan nilai yang tidak berbeda jauh secara spasial maupun vertikal yaitu antara 4,52 - 7,25 $\mathrm{mg} / \mathrm{L}$. Selain itu, profil vertikal DO juga menunjukkan penurunan nilai dimana lapisan atas lebih kaya oksigen dibanding lapisan bawah. Nilai salinitas menunjukkan rentang yang sempit yaitu antara 33,07 - 34,61 psu dan tampak adanya kenaikan salinitas secara vertikal dari lapisan permukaan ke lapisan yang lebih dalam. Nilai suhu juga menunjukkan rentang yang sempit antara $24,57-29,98^{\circ} \mathrm{C}$ dengan kecenderungan terjadinya penurunan nilai suhu, yaitu lapisan bawah lebih dingin dibanding dengan lapisan permukaan.
Konsentrasi nutrien bervariasi di setiap lokasi, secara umum nilai $\mathrm{SiO}_{3}>\mathrm{DIN}>\mathrm{PO}_{4}$. Distribusi vertikal $\mathrm{SiO}_{3}, \quad \mathrm{PO}_{4}$ dan DIN menunjukkan kecenderungan berfluktuasi dengan pola yang berbeda pada setiap stasiun. Konsentrasi $\mathrm{SiO}_{3}$ berada pada rentang $0,082-0,361 \mathrm{mg} / \mathrm{L}$ dan cenderung mengalami kenaikan dari lapisan permukaan ke lapisan bawah di stasiun 2, 3 dan 4 . Kecenderungan penurunan terjadi di stasiun 1, 5, 6 dan 7. Rentang konsentrasi $\mathrm{PO}_{4}$ berkisar antara $0,004-0,022 \mathrm{mg} / \mathrm{L}$, dengan sebaran vertikal yang menurun ke arah lapisan lebih dalam. Kecenderungan turunnya konsentrasi $\mathrm{PO}_{4}$ tampak hampir di semua stasiun sehingga lapisan pemukaan lebih kaya $\mathrm{PO}_{4}$ dibandingkan lapisan yang lebih dalam. Berkebalikan dengan $\mathrm{PO}_{4}$, profil vertikal DIN didominasi oleh kenaikan konsentrasi sehingga lapisan bawah memiliki konsentrasi DIN yang lebih besar dibanding lapisan atas.

Distribusi nutrien secara horizontal berfluktuasi. Konsentrasi nutrien dari stasiun $1 \mathrm{ke}$ stasiun 3 mengalami penurunan kemudian meningkat sampai stasiun 4. Pola selanjutnya terlihat bahwa konsentrasi meningkat kembali dari stasiun 5 sampai stasiun 7, kecuali untuk fosfat dan silikat konsentrasi maksimum terdapat di stasiun 6 .

Tabel 1. Kualitas Air di Laut Jawa-Ambang Dewakang

Table 1. Water quality in Java -Ambang Dewakang Sea

\begin{tabular}{|c|c|c|c|c|c|c|c|c|c|c|c|}
\hline \multirow[b]{2}{*}{ St } & \multirow[b]{2}{*}{$\begin{array}{c}\text { Kedala } \\
\text { man } \\
(\mathrm{m})\end{array}$} & \multicolumn{10}{|c|}{ Parameter } \\
\hline & & $\mathrm{pH}$ & $\begin{array}{c}\mathrm{DO} \\
(\mathrm{mg} / \mathrm{l})\end{array}$ & $\begin{array}{c}\mathrm{SiO}_{3} \\
(\mathrm{mg} / \mathrm{l})\end{array}$ & $\begin{array}{c}\mathrm{PO}_{4} \\
(\mathrm{mg} / \mathrm{l})\end{array}$ & DIN & $\mathrm{N} / \mathrm{P}$ & $\mathrm{N} / \mathrm{Si}$ & $\mathrm{Si} / \mathrm{P}$ & $\begin{array}{c}\text { Salinit } \\
\text { as } \\
\text { (psu) }\end{array}$ & $\begin{array}{c}\text { Suhu } \\
\left({ }^{\circ} \mathrm{C}\right)\end{array}$ \\
\hline \multirow[t]{2}{*}{1} & 5 & 7,95 & 6,26 & 0,145 & 0,015 & 0,091 & 6,1 & 0,63 & 9,7 & 33,07 & 29,98 \\
\hline & 45 & 7,94 & 6,22 & 0,132 & 0,006 & 0,081 & 13,6 & 0,62 & 22,0 & 34,24 & 29,28 \\
\hline \multirow[t]{2}{*}{2} & 5 & 7,99 & 7,25 & 0,082 & 0,019 & 0,090 & 4,7 & 1,10 & 4,3 & 34,52 & 29,94 \\
\hline & 65 & 7,95 & 5,77 & 0,125 & 0,006 & 0,084 & 14,0 & 0,67 & 20,8 & 34,61 & 28,97 \\
\hline \multirow[t]{2}{*}{3} & 5 & 7,94 & 5,88 & 0,101 & 0,005 & 0,070 & 14,0 & 0,69 & 20,2 & 34,19 & 29,67 \\
\hline & 65 & 7,91 & 5,82 & 0,126 & 0,004 & 0,080 & 20,0 & 0,63 & 31,5 & 34,54 & 29,05 \\
\hline \multirow[t]{3}{*}{4} & 5 & 7,92 & 5,62 & 0,084 & 0,015 & 0,114 & 7,6 & 1,36 & 5,6 & 34,41 & 29,93 \\
\hline & 50 & 7,91 & 5,53 & 0,130 & 0,009 & 0,077 & 8,6 & 0,59 & 14,4 & 34,50 & 28,86 \\
\hline & 90 & 7,84 & 4,52 & 0,319 & 0,022 & 0,180 & 8,2 & 0,57 & 14,5 & 34,52 & 24,57 \\
\hline \multirow[t]{2}{*}{5} & 5 & 7,95 & 5,86 & 0,190 & 0,005 & 0,076 & 15,1 & 0,40 & 38,0 & 34,35 & 29,96 \\
\hline & 75 & 7,91 & 5,58 & 0,098 & 0,004 & 0,090 & 22,5 & 0,92 & 24,5 & 34,46 & 28,41 \\
\hline \multirow[t]{2}{*}{6} & 5 & 7,97 & 5,29 & 0,361 & 0,005 & 0,076 & 15,2 & 0,21 & 72,2 & 34,21 & 29,91 \\
\hline & 75 & 7,86 & 4,91 & 0,165 & 0,022 & 0,114 & 5,2 & 0,69 & 7,5 & 34,32 & 28,15 \\
\hline \multirow[t]{2}{*}{7} & 5 & 7,95 & 6,30 & 0,164 & 0,004 & 0,093 & 23,2 & 0,57 & 41,0 & 33,88 & 29,60 \\
\hline & 75 & 7,86 & 5,68 & 0,159 & 0,006 & 0,124 & 20,6 & 0,78 & 26,5 & 34,31 & 28,10 \\
\hline \multicolumn{2}{|c|}{ average } & 7,92 & 5,77 & 0,159 & 0,010 & 0,096 & 13,24 & 0,69 & 23,52 & 34,28 & 28,96 \\
\hline \multicolumn{2}{|r|}{$\max$} & 7,99 & 7,25 & 0,361 & 0,022 & 0,180 & 23,25 & 1,36 & 72,20 & 34,61 & 29,98 \\
\hline \multicolumn{2}{|r|}{$\min$} & 7,84 & 4,52 & 0,082 & 0,004 & 0,070 & 4,73 & 0,21 & 4,32 & 33,07 & 24,57 \\
\hline \multicolumn{2}{|r|}{ St dev } & 0,043 & 0,631 & 0,080 & 0,007 & 0,028 & 6,34 & 0,27 & 17,49 & 0,38 & 1,38 \\
\hline
\end{tabular}


Rasio nutrien dihitung untuk unsur N/P; N/Si dan Si/P untuk mengetahui unsur pembatas pertumbuhan fitoplankton dari ketiga nutrien tersebut. Rasio N/P dan Si/P menunjukkan angka $>1$ di semua stasiun yang mengindikasikan bahwa konsentrasi $\mathrm{P}$ selalu lebih rendah dibandingkan $\mathrm{N}$ dan $\mathrm{Si}$ di semua stasiun. Rasio N/Si didominasi angka $<1$ hampir di semua stasiun kecuali stasiun 2 dan 4 di lapisan atas $(5 \mathrm{~m})$. Hal tersebut mengisyaratkan konsentrasi $\mathrm{N}$ lebih rendah dibandingkan Si.

Hasil pengukuran terhadap parameter fisika perairan yang meliputi sebaran vertikal suhu, densitas, salinitas, DO dan turbiditas disajikan pada Gambar 2. Rangkaian gambar tersebut menunjukkan bahwa suhu, densitas, dan DO tidak bervariasi tajam baik secara horizontal maupun vertikal hingga kedalaman $75 \mathrm{~m}$. Perbedaan nilai masing-masing parameter tampak nyata di bawah kedalaman tersebut meskipun tampak adanya anomali DO di lapisan permukaan pada stasiun 2 . Salinitas menunjukkan gradasi yang jelas di lapisan permukaan dan cenderung homogen di bawah kedalaman $100 \mathrm{~m}$. Turbiditas menunjukkan pola yang paling berbeda diantara parameter lain, yaitu homogen secara vertikal di stasiun 5, 6 dan 7 .
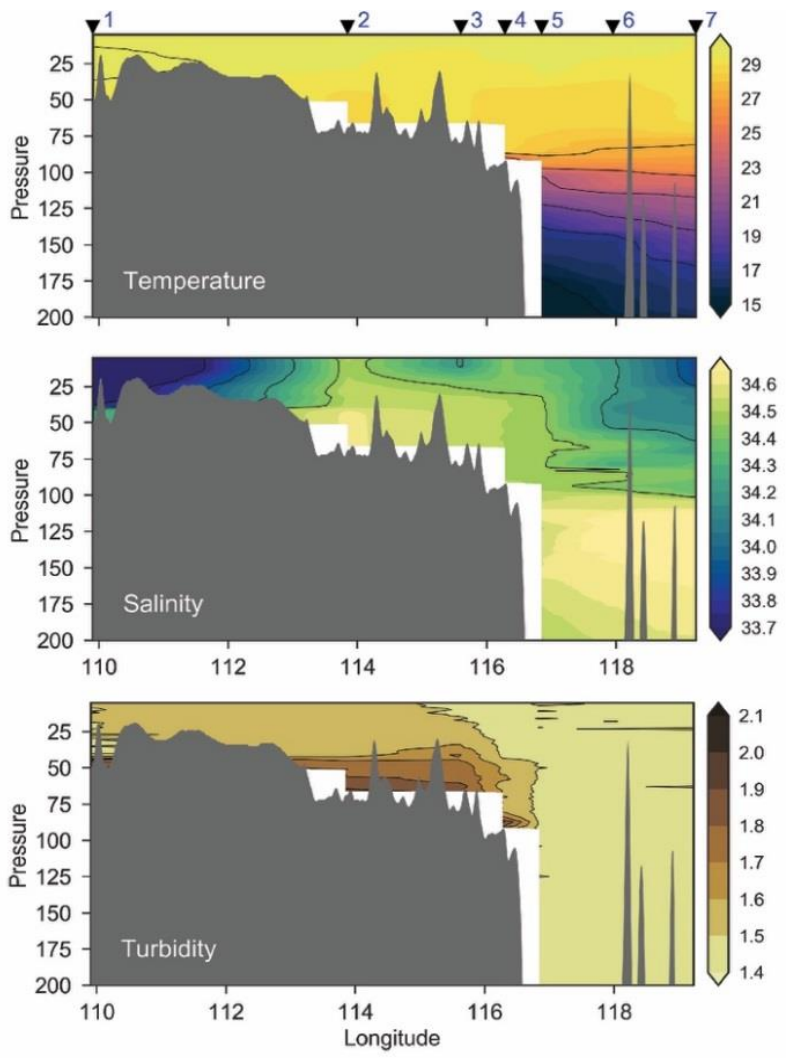

Karakteristik massa air di stasiun pengamatan disajikan dalam bentuk diagram TS (Suhu Potensial-Salinitas) pada Gambar 3. Stasiun 1, 2 dan 3 yang berlokasi di Laut Jawa yang lebih dangkal menunjukkan pola korelasi TS yang berbeda dibanding stasiun $4-7$ yang terletak di perairan Ambang Dewakang yang merupakan perairan lebih dalam. Stasiun 1 lebih sensitif terhadap perubahan salinitas dibandingkan stasiun lainnya, sementara stasiun 4-7 menunjukkan kecenderungan salinitas yang stabil. Hal tersebut mengindikasikan bahwa massa air di stasiun $1-3$ menunjukkan perbedaan karakter dengan stasiun 4 - 7. Diagram-TS (Diagram Suhu - Salinitas) tersebut mengkonfirmasi adanya kondisi pencampuran isopiknal (isopycnal mixing) pada garis isopiknal $23-25.5 \mathrm{~kg} / \mathrm{m}^{3}$ di wilayah perairan timur yang lebih dalam hingga perbatasan perairan dangkal (St. 5, 6 dan 7). Selain itu, terdapat pula percampuran vertikal (diapycnal mixing) pada garis isopiknal $<23 \mathrm{~kg} / \mathrm{m}^{3}$ yang mengindikasikan salinitas yang tinggi pada lapisan dekat permukaan, jika dibandingkan dengan stasiun Stasiun 4 dan Stasiun 6.
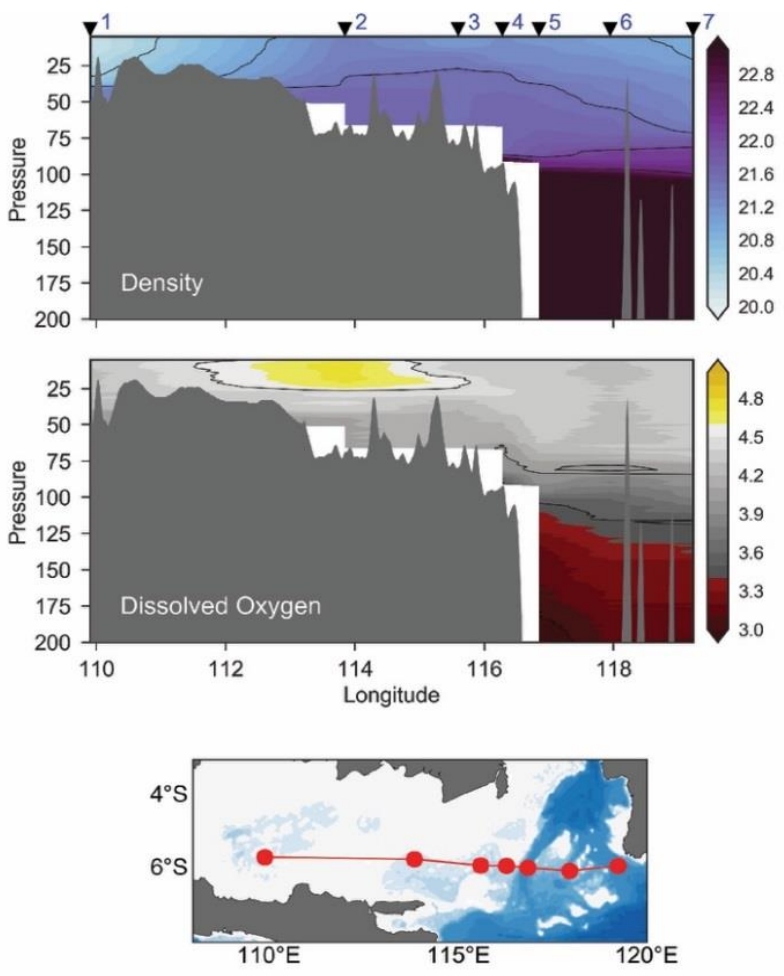

Gambar 2. Profil menegak suhu $\left({ }^{\circ} \mathrm{C}\right)$, salinitas (psu), turbiditas, densitas (sigma theta, $\left.\mathrm{kg} \mathrm{m}^{-3}\right)$, dan DO (ml/l) di sepanjang transek dari Laut Jawa (kiri) hingga Ambang Dewakang (kanan).

Figure 2. Vertical Profile of temperature $\left({ }^{\circ} \mathrm{C}\right.$ ), salinity ( $\mathrm{psu}$ ), turbidity, density (sigma theta, $\mathrm{kg} \mathrm{m}^{-3}$ ), and DO (ml/l) at transect from Java Sea (left) to Ambang Dewakang (right). 
Stabilitas statik air laut digambarkan dari profil frekuensi Brunt-Vaisala yang ditunjukkan pada Gambar 4. Nilai frekuensi Brunt-Vaisala menunjukkan tingkat kestabilan perairan, frekuensi rendah menunjukan kolom air yang tidak stabil. Dari hasil perhitungan tampak bahwa pada lapisan 0 - 40 bar memiliki nilai frekuensi Brunt-Vaisala yang kecil terutama pada stasiun $1-4$. Hal ini mengisyaratkan bahwa lapisan permukaan di stasiun $1-4$ lebih tidak stabil dibandingkan stasiun $5-7$. Nilai frekuensi Brunt-Vaisala di stasiun 5 7 menunjukkan denyut menurun dimana nilai frekuensi tinggi teramati di lapisan atas sementara lapisan bawah memiliki nilai frekuensi yang cenderung kecil.

Hubungan antara nutrien dengan salinitas dan suhu ditunjukkan pada Tabel 2. Hasil analisis dengan menggunakan korelasi Pearson menunjukkan terdapat korelasi yang signifikan antara $\mathrm{pH}$ dengan DIN $(\mathrm{r}=-0,745)$, suhu $(\mathrm{r}=$ $0,814)$, dan DO $(r=0,754)$ pada $p<0,01$. Selain berkorelasi dengan $\mathrm{pH}$, DIN berkorelasi signifikan dengan fosfat $(\mathrm{r}=0,645, \mathrm{p}<0,01)$ dan suhu $(\mathrm{r}=$ $0,847, \mathrm{p}<0,01)$, juga cukup signifikan terhadap DO $(r=-0,545, p<0,05)$. Sementara itu, DO signifikan terhadap suhu $(\mathrm{r}=0,685, \mathrm{p}<0,01)$ dan cukup signifikan terhadap silikat $(r=-0,575, \mathrm{p}<0,05)$.

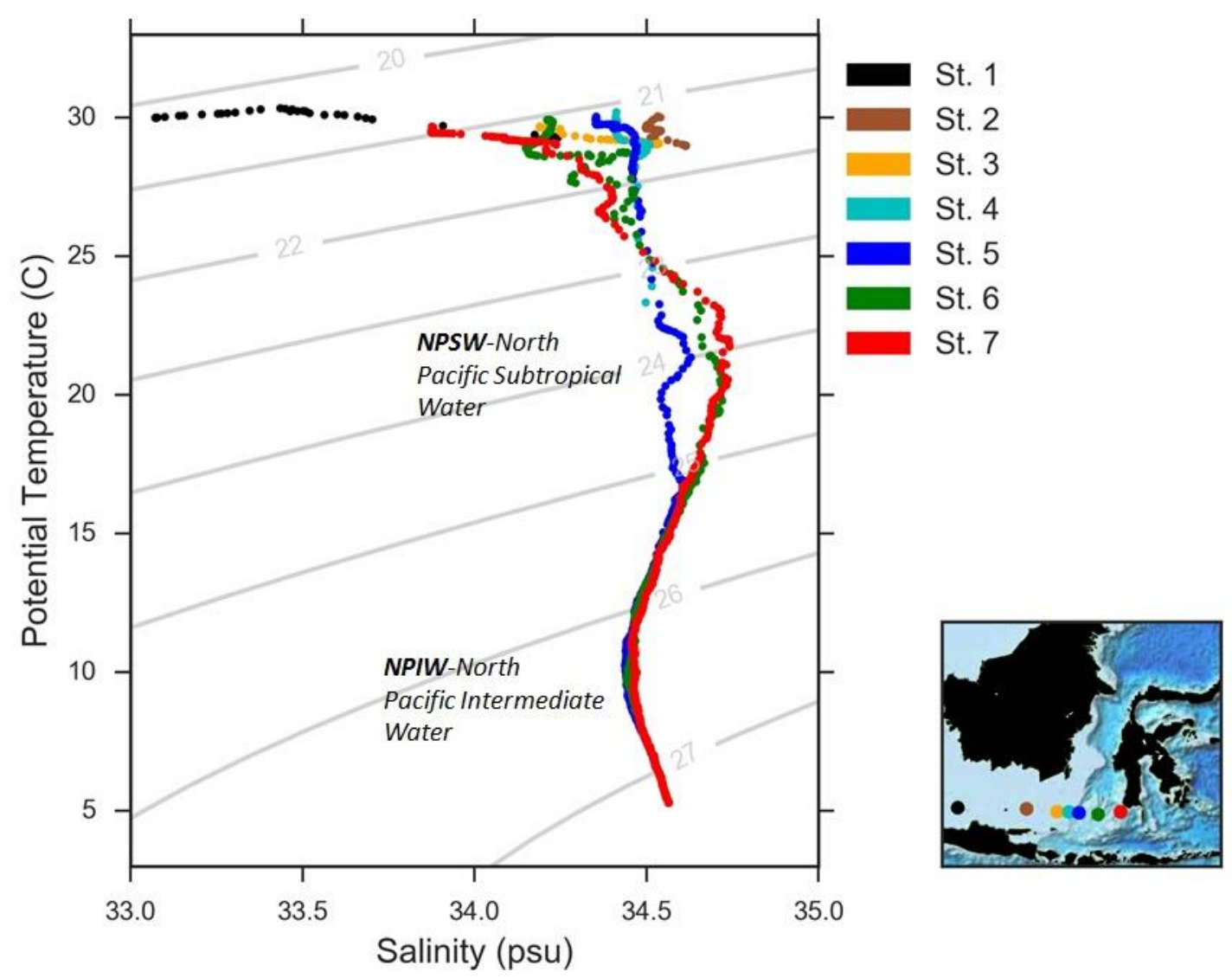

Gambar 3. Diagram TS (Suhu Potensial-Salinitas) pada Stasiun 1 (bagian barat, Laut Jawa) hingga Stasiun 7 (bagian timur, Perairan Dewakang) serta karakteristik massa air lapisan atas Samudera Pasifik (NPSW, North Pacific Subtropical Water) dan massa air lapisan menengah Samudera Pasifik (NPIW, North Pacific Intermediate Water).

Figure 3. TS Diagram (Potential Temperature-Salinity) at Station 1 (western, Java Sea) to Station 7 (Easthern, Dekawang) and water massescharacteristics of NPSW (North Pacific Subtropical Water) and NPIW (North Pacific Intermediate Water). 
Oseanologi dan Limnologi di Indonesia 2019 4(1):41-52
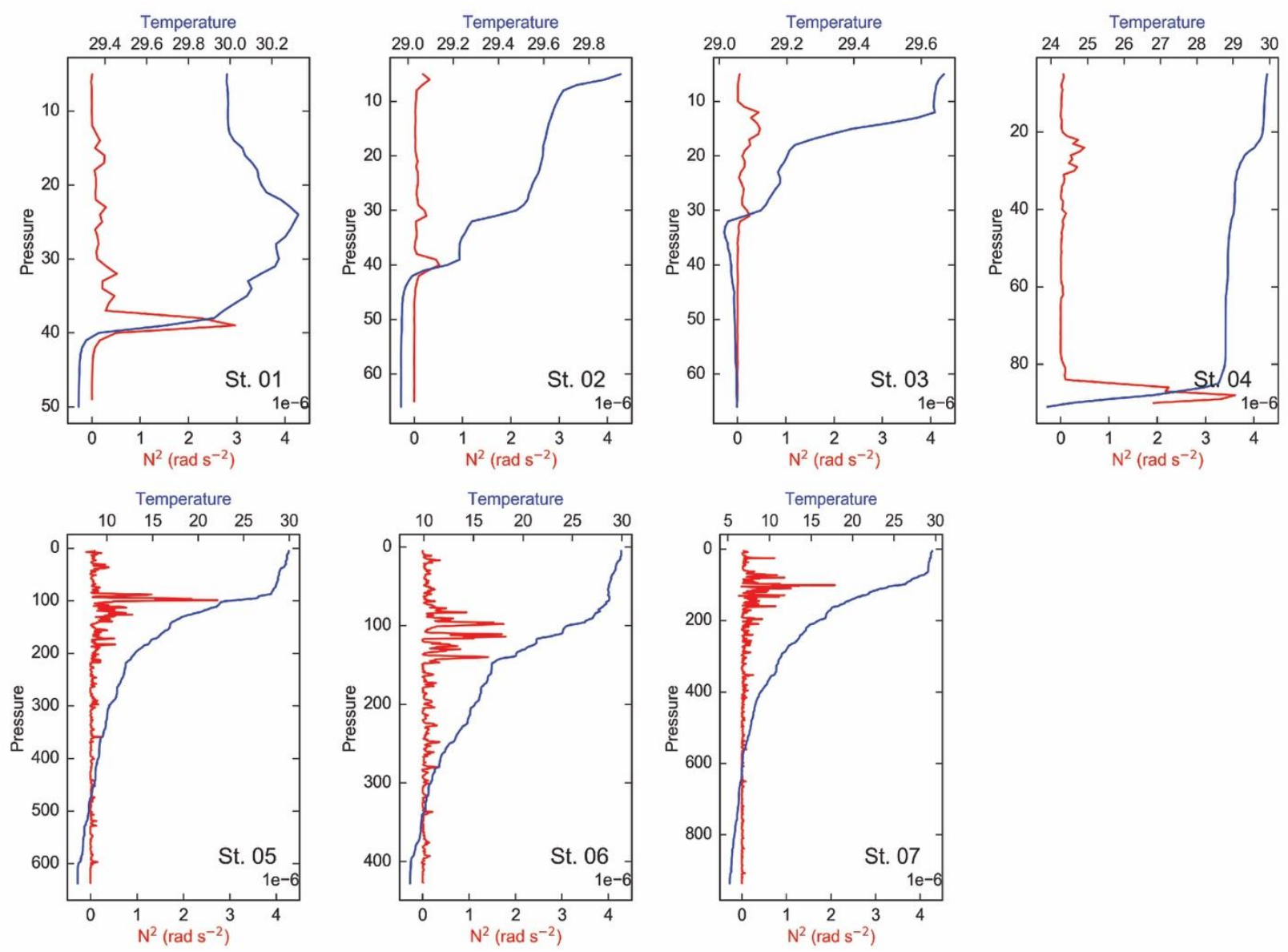

Gambar 4. Frekuensi Brunt-Vaisala $\left(\mathrm{N}^{2}\right)$ dan suhu dari 7 profil CTD

Figure 4. Brunt-Vaisala frequency $\left(\mathrm{N}^{2}\right)$ and temperature from 7 CTD profile 
Tabel 2. Korelasi antara parameter fisika dan kimia

Table 2. Correlation between physical and chemical parameter

Correlations

\begin{tabular}{llrrrrrrr}
\hline & & $\mathrm{pH}$ & silicate & phosphate & DIN & salinity & temperature & DO \\
\hline $\mathrm{pH}$ & Pearson Correlation & 1 & -.193 & -.344 & $-.745^{* *}$ & -.243 & $.814^{* *}$ & $.754^{* *}$ \\
& Sig. (2-tailed) & & .490 & .210 & .001 & .383 & .000 & .001 \\
& $\mathrm{~N}$ & 15 & 15 & 15 & 15 & 15 & 15 & 15 \\
\hline silicate & Pearson Correlation & -.193 & 1 & .103 & .375 & -.041 & -.425 & $-.575^{*}$ \\
& Sig. (2-tailed) & .490 & & .716 & .169 & .885 & .115 & .025 \\
& $\mathrm{~N}$ & 15 & 15 & 15 & 15 & 15 & 15 & 15 \\
\hline phosphate & Pearson Correlation & -.344 & .103 & 1 & $.645^{* *}$ & -.033 & -.422 & -.206 \\
& Sig. (2-tailed) & .210 & .716 & & .009 & .908 & .117 & .460 \\
& $\mathrm{~N}$ & 15 & 15 & 15 & 15 & 15 & 15 & 15 \\
\hline DIN & Pearson Correlation & $-.745^{* *}$ & .375 & $.645^{* *}$ & 1 & .130 & $-.847^{* *}$ & $-.545^{*}$ \\
& Sig. (2-tailed) & .001 & .169 & .009 & & .645 & .000 & .036 \\
& $\mathrm{~N}$ & 15 & 15 & 15 & 15 & 15 & 15 & 15 \\
\hline salinity & Pearson Correlation & -.243 & -.041 & -.033 & .130 & 1 & -.326 & -.257 \\
& Sig. (2-tailed) & .383 & .885 & .908 & .645 & & .236 & .354 \\
& $\mathrm{~N}$ & 15 & 15 & 15 & 15 & 15 & 15 & 15 \\
\hline temperature & Pearson Correlation & $.814^{* *}$ & -.425 & -.422 & $-.847^{* *}$ & -.326 & 1 & $.685^{* *}$ \\
& Sig. (2-tailed) & .000 & .115 & .117 & .000 & .236 & & .005 \\
& $\mathrm{~N}$ & 15 & 15 & 15 & 15 & 15 & 15 & 15 \\
\hline DO & Pearson Correlation & $.754^{* *}$ & $-.575^{*}$ & -.206 & $-.545^{*}$ & -.257 & $.685^{* *}$ & 1 \\
& Sig. (2-tailed) & .001 & .025 & .460 & .036 & .354 & .005 & \\
& $\mathrm{~N}$ & 15 & 15 & 15 & 15 & 15 & 15 & 15 \\
\hline
\end{tabular}

**. Correlation is significant at the 0.01 level (2-tailed).

*. Correlation is significant at the 0.05 level (2-tailed).

\section{Pembahasan}

Laut Jawa merupakan perairan dangkal yang memiliki salinitas rendah karena letaknya diantara Pulau Kalimantan, Jawa, Sumatera dan Sulawesi yang memasok air tawar dari muara sungai-sungai besar pulau tersebut ke Laut Jawa. Kondisi topografi perairan Laut Jawa yang dangkal sehingga terjadi kondisi pencampuran ditandai dengan lapisan homogen dari permukaan hingga dasar perairan (Gambar 2; Suhu dan Salinitas), serta ketidakstabilan kolom air dari frekuensi Brunt-Vaisala (Gambar 4). Secara umum variasi Sea Surface Temperature (SST) di perairan tropis bersuhu hangat dengan sedikit variasi tahunan. Berbeda dengan suhu, salinitas Laut Jawa lebih bervariasi karena selain dipengaruhi oleh river runoff disebelah barat dari tiga gugusan kepulauan besar Indonesia, juga dipengaruhi oleh sisipan massa air bersalinitas tinggi dari wilayah Timur sehingga memiliki properti massa air yang unik.
Sama halnya dengan perairan Indonesia lainnya, kondisi oseanografi Laut Jawa sangat dipengaruhi oleh siklus semi-tahunan monsun. Pergantian arah angin pada siklus monsun akan mempengaruhi variasi arus dan massa air tahunan. Selain itu, kondisi pasut, keberadaan diantara Samudera Pasifik dan Hindia turut berkontribusi terhadap kondisi massa air Laut Jawa yang pada akhirnya akan mempengaruhi kondisi biologis, biogeokimia perairan, hingga kondisi ekosistem perikanan.

Selama musim barat (northwest monsoon) yang berlangsung selama Desember - Februari angin bertiup dari barat menuju timur. Berdasarkan data komposit musiman tahun 2003-2013 terekam massa air dengan suhu dingin di perairan Selat Karimata yang berkisar antara $29,12-30,55{ }^{\circ} \mathrm{C}$. Suhu dingin ini mencirikan pergerakan massa air Laut Cina Selatan yang bergerak memasuki Selat Karimata menuju Laut Flores melalui Laut Jawa. Sebaliknya selama musim timur (southeast 
monsoon) yang berlangsung selama Juni - Agustus angin berhembus dari timur ke arah barat. Selat Karimata cenderung lebih hangat dibandingkan musim barat, hal ini akibat pengaruh massa air yang berasal dari Laut Flores yang bergerak ke Laut Cina Selatan yang memiliki karakteristik suhu yang dingin (Wyrtki 1961).

Profil suhu di Laut Jawa (St. 1, 2 dan 3) cenderung homogen karena Laut Jawa merupakan perairan dangkal dengan kedalaman rata-rata sekitar $50 \mathrm{~m}$. Dangkalnya perairan tersebut menyebabkan pengaruh angin dan penetrasi energi dari matahari memainkan peranan dalam memengaruhi suhu pada kolom air. Profil suhu dari perairan Masalembo hingga Ambang Dewakang (St. 4, 5, 6 dan 7) cenderung terstratifikasi karena kedalaman yang lebih besar dibanding Laut Jawa. Kondisi stratifikasi dapat terlihat pada profil suhu yang ditunjukan dengan menurunnya nilai suhu seiring dengan bertambahnya kedalaman. Identik dengan suhu, nilai densitas semakin tinggi seiring bertambahnya kedalaman, karena densitas merupakan fungsi dari suhu dan salinitas.

Kolom massa air Laut Jawa tampak lebih tawar (salinitas < 33.8 psu) dibandingkan wilayah Ambang Dewakang dan selatan Selat Makassar. Hal ini karena Laut Jawa dipengaruhi oleh asupan air tawar dari Laut China Selatan serta muara sungai pulau-pulau sekelilingnya (Koch-Larrouy et al. 2008). Selain itu, profil salinitas Laut Jawa lebih tawar dibandingkan perairan lain di Timur Indonesia karena pengaruh presipitasi yang relatif tinggi selama musim barat (Pramuwardani et al. 2018). Pada wilayah ujung timur Laut Jawa hingga Perairan Masalembo (St. 3, 4 dan 5) salinitas cenderung lebih tinggi di bandingkan Laut Jawa pada kedalaman $30-50 \mathrm{~m}$, dan jika dilihat dari kontur, salinitas tinggi ini tampak menyisip dari kedalaman maksimum di selatan Selat Makassar (St. 6, 7). Perairan Masalembo merupakan wilayah perairan transisi yang mengubungkan perairan dangkal (Laut Jawa) di sebelah barat dan perairan dalam (selatan Selat Makassar hingga Laut Flores) di sebelah Timur sehingga profil wilayah ini akan dipengaruhi oleh kolom air dari dua sisi wilayah yang berbeda. Wilayah Laut Jawa juga merupakan wilayah perairan dengan kekeruhan yang tinggi sebagai indikasi adanya pengaruh oleh suspensi terlarut dari sungai membawa massa air tawar .

Ketidakstabilan kolom air dapat memicu terjadi pencampuran massa air (Gambar 4). Semakin tinggi frekuensi Brunt-Vaisala maka semakin tinggi stabilitas statik kolom air, sebaliknya jika semakin rendah maka kolom air semakin tidak stabil. Dari semua profil CTD, nilai frekuensi yang tinggi rata-rata ditemukan pada kedalaman $80-200 \mathrm{~m}$ yang merupakan lapisan termoklin (St. 4, 5, 6 dan 7). Di wilayah Laut Jawa (St. 1 dan 2) nilai frekuensi cenderung bernilai nol, begitu pula pada perairan Masalembo (St. 3 dan St. 4) pada kedalaman permukaan hingga $80 \mathrm{~m}$ yang mengindikasikan kolom air yang tidak stabil dan memicu terjadinya turbulensi. Dengan kata lain diduga karena ketidakstabilan kolom air diperairan Masalembo inilah yang memicu terjadinya sisipan air salinitas tinggi dari Ambang Dewakang.

Perairan Masalembo (stasiun 3-5), merupakan batas antara perairan dangkal Laut Jawa dengan perairan laut dalam di lereng Paparan Sunda bagian timur. Hasil pemetaan wilayah perairan ini (Gambar 2) pada bulan November menunjukan bahwa stasiun 3 dan 4 di Perairan Masalembo diduga merupakan kawasan turbulen. Dugaan tersebut diindikasikan karena ketidakstabilan kolom air yang diduga dapat mengangkat lapisan piknoklin hingga perairan Laut Jawa bagian timur dan membuat garis isopiknal dan kadar oksigen terlarut tampak terangkat (Gambar 2. Densitas dan Oksigen terlarut). Dari riset sebelumnya (Risko et al. 2016) menyatakan bahwa ambang Dewakang merupakan kawasan turbulensi aktif dengan nilai energi turbulensi kinetik $(\varepsilon)$ dan difusivitas turbulensi $(K \rho)$ yang relatif tinggi $O(1.08 \times 10-6) \mathrm{Wkg}^{-1}$ dan $O(2.84 \times 10-4) \mathrm{m}^{2} \mathrm{~s}^{-1}$.

Nilai $\mathrm{pH}$ di perairan Laut Jawa masih memenuhi baku mutu yang ditetapkan KLH tahun 2004 yaitu antara $7-8,5$. Kondisi perairan yang bersifat sangat asam atau sangat basa akan membahayakan kelangsungan hidup organisme karena akan menyebabkan terjadinya gangguan metabolisme dan respirasi. Nilai DO di lokasi penelitian termasuk tinggi berdasarkan European Water Framework Directive (Best 2007). Hal ini menandakan bahwa kualitas perairan di Laut Jawa masih tergolong baik. Sumber utama oksigen di laut berasal dari pertukaran gas antara oksigen di atmosfer dengan permukaan laut dan berasal dari produksi insitu melalui fotosintesis. Penurunan oksigen disebabkan oleh penggunaan oksigen yang besar oleh aktivitas bakteri untuk memecah bahan organik.

Rata-rata kadar DIN yang terukur di perairan laut Jawa termasuk dalam kategori sedang sedangkan konsentrasi $\mathrm{PO}_{4}-\mathrm{P}$ berada dalam kategori baik (UNEP 2007). Dari hasil tersebut dapat disimpulkan bahwa Laut Jawa masih dalam kondisi baik dan belum mengalami pengayaan nutrien. Secara horizontal, konsentrasi nutrien berfluktuasi sebagai akibat pergerakan massa air, proses estuari, aktivitas biologis dan aktivitas antropogenik (Liu et al. 2005). Konsentrasi DIN, fosfat, dan silikat memiliki pola yang sama yaitu konsentrasi maksimum berada di stasiun 4 dan stasiun 6. Hal ini berkaitan dengan proses fisika 
yang terjadi dimana terdapat perbedaan karakteristik sifat fisika antara Laut Jawa (St. 1, 2, dan 3) dan perairan Masalembo hingga Ambang Dewakang (St. 4, 5, 6 dan 7). Distribusi nutrien tertinggi berada di daerah Ambang Dewakang, hal ini berkaitan dengan proses turbulensi di perairan tersebut sehingga mengangkat nutrien dari lapisan bawah ke lapisan permukaan.

Secara vertikal, konsentrasi nutrien di Laut Jawa-Ambang Dewakang cenderung meningkat ke arah lapisan dalam, kecuali untuk Stasiun 1 sampai 3 konsentrasinya menurun. Hal ini dapat disebabkan oleh penyerapan nutrien oleh fitoplankton yang berlangsung cepat menyebabkan nutrien yang berkurang ( $\mathrm{Li}$ et al. 2015). Selain itu, kondisi fisis laut Jawa yang dangkal memungkinkan proses pencampuran nutrien dari lapisan dasar ke lapisan permukaan sehingga nutrien bisa dimanfaatkan fitoplankton. Menurut Sachoemar dan Yanagi (2001), perairan dangkal umumnya memiliki konsentrasi nutrien tertinggi di dasar perairan sebagai akibat dari proses dekomposisi yang tinggi dan demineralisasi material organik di lapisan dasar. Dari ketiga nutrien yang diukur, silikat memiliki konsentrasi tertinggi di lapisan dasar yang disebabkan oleh tingginya laju pelapukan mineral silikat yang didorong oleh kenaikan $\mathrm{CO}_{2}$ di atmosfer (Wei et al. 2015).

Dari hasil korelasi antara parameter fisika dan kimia (Tabel 2) diketahui bahwa terdapat hubungan antara $\mathrm{pH}$ dengan DIN, suhu, dan DO. Hubungan antara $\mathrm{pH}$ dengan DIN berkorelasi negatif. Hal ini mengindikasikan bahwa konsentrasi nitrogen yang tinggi bisa menyebabkan kondisi air laut yang semakin asam. Hasil ini sesuai dengan penelitian mengenai distribusi nutrien dan pengaruhnya terhadap keasaman air laut yang dilakukan oleh Zhang dan Gao (2016) di bagian barat daya Laizhou, Cina. Proses respirasi fitoplankton akan melepaskan $\mathrm{CO}_{2}$ yang akan menurunkan $\mathrm{pH}$, tetapi setiap spesies memiliki pola dan laju respirasi yang berbeda sehingga penurunan $\mathrm{pH}$ pun akan berbeda (Zhang and Gao 2016).

Sementara itu, hubungan antara $\mathrm{pH}$ dengan suhu dan DO berkorelasi positif. Perubahan $\mathrm{pH}$ dan DO dipengaruhi oleh fotosintesis alga, respirasi, suhu air, dan dekomposisi senyawa organik. Namun demikian, konsumsi dan produksi karbon dioksida sering diikuti oleh produksi dan konsumsi oksigen. Jika $\mathrm{pH}$ menurun (ion $\mathrm{H}^{+}$ meningkat), akan menyebabkan ion hidrogen dan oksigen bereaksi membentuk air $\left(\mathrm{H}_{2} \mathrm{O}\right)$ sehingga oksigen terlarut menurun (Zang et al. 2011).

Nilai $\mathrm{pH}$ pun dipengaruhi oleh suhu air karena suhu air secara tidak langsung mengontrol laju fotosintesis dan respirasi biota melalui enzim. Kelarutan karbon dioksida juga dipengaruhi oleh suhu. Ketika suhu air meningkat maka laju kinetik karbon dioksida pun meningkat. Ketika karbon dioksida lepas dari permukaan air, maka kelarutannya pun menurun (Zang et al. 2011).

Selain itu, DIN memiliki korelasi positif dengan fosfat dan berkorelasi negatif terhadap suhu dan DO. Korelasi antara DIN dan fosfat yaitu memiliki pola yang sama secara horizontal sehingga dapat dikatakan bahwa DIN dan fosfat diserap oleh fitoplankton secara bersamaan. Korelasi negatif antara DIN terhadap suhu disebabkan fitoplankton masih memanfaatkan DIN untuk pertumbuhannya pada lapisan eufotik sedangkan pada lapisan dalam yang suhunya semakin kecil tidak banyak dimanfaatkan sehingga konsentrasi nutrien semakin besar. Nitrat dimanfaatkan fitoplankton untuk proses fotosintesis (produktivitas primer) pada daerah eufotik (Millero and Sohn 1992). Demikian pula korelasi yang terjadi antara DIN dengan DO, senyawa nitrogen (nitrat, nitrit, dan amonium) membutuhkan oksigen terlarut untuk proses nitrifikasi sehingga pada saat konsentrasi DIN tinggi maka nilai DO menurun.

Hal lainnya menunjukkan bahwa penelitian di Laut Jawa tidak ada korelasi antara konsentrasi nutrien dengan salinitas. Hal ini dikarenakan lokasi penelitian berada di laut terbuka sehingga perbedaan salinitasnya tidak terlalu jauh. Berbeda hal nya dengan hasil penelitian Li et al. (2015) yang menyebutkan bahwa hubungan nutrien dan salinitas berkorelasi negatif karena berada di lokasi dari pesisir sampai laut sehingga diindikasikan terjadi percampuran nutrien dan salinitas antara daerah pesisir dan laut. Perbedaan hasil yang terjadi disebabkan hubungan antara salinitas dan nutrien ini tidak selalu bertahan karena berbagai proses seperti aktivitas biologis, pencampuran, dan remineralisasi (Cardona et al. 2016)

Stoikoimetri nutrien di laut biasa digunakan untuk menentukan elemen pembatas dari pertumbuhan fitoplankton di ekosistem laut. Rasio mol N/P berkisar antara 4,7 - 23,2 dengan rata-rata 13,24. Rasio mol N/Si berkisar antara 0,21 - 1,36 dengan rata-rata 0,70 . Rasio mol $\mathrm{Si} / \mathrm{P}$ berkisar antara 4,3-72,2 dengan rata-rata 17,49. Bila rasio DIN dan DIP tinggi atau lebih besar dari 16 maka yang menjadi pembatas pertumbuhan fitoplankton adalah DIP, sebaliknya bila rasio DIN dan DIP lebih kecil dari 16 maka yang menjadi pembatasnya adalah DIN. Dari hasil diatas menunjukkan yang menjadi pembatas pertumbuhan fitoplankton di laut Jawa adalah DIN.

Rasio redfield dapat pula mengetahui struktur komposisi komunitas fitoplankton. 
Perbandingan nitrat, silika dan fosfat untuk pertumbuhan fitopankton yang baik adalah 16:16:1 (Suthers et al. 2009). Di perairan terbuka Samudera Atlantik Utara pada lintang sedang, konsentrasi DIN dan DIP berhubungan dengan peledakan fitoplankton yang menyebabkan biomassa fitoplankton terakumulasi. Ini disebabkan pencampuran dan penambahan nutrien dari perairan lebih dalam ke lapisan permukaan atas (USEPA, 2001). Selain itu jika rasio DIN/DIP tinggi seperti yang terjadi di Laut Kuning Selatan China yang berkisar antara 22,77 - 97,74 maka berakibat terjadi ledakan alga hijau yang bisa mengganggu ekosistem (Li et al. 2015). Perubahan rasio nutrien dapat mengubah komposisi komunitas fitoplankton.

\section{Kesimpulan}

Secara umum variasi suhu dan salinitas diperairan Laut Jawa menunjukkan kondisi homogen, akibat pengaruh proses mixing di perairan dangkal. Sisipan massa air bersalinitas tinggi dari lapisan air yang lebih dalam di timur Laut Jawa (Ambang Dewakang) menghasilkan karakteristik massa air yang unik, proses pencampuran (mixing) di daerah perbatasan antara keduanya memengaruhi salinitas tinggi diwilayah tersebut. Dari nilai konsentrasi nutrien tersebut dapat dikatakan bahwa kualitas perairan Laut Jawa berada pada kategori moderate (sedang). Nitrogen merupakan faktor pembatas bagi produksi primer di Laut Jawa. Parameter fisika dan kimia di lokasi penelitian terindikasi saling mempengaruhi satu sama lain.

\section{Persantunan}

Penelitian ini merupakan hasil riset Joint Research Cruise LIPI-IOCAS tahun 2014. Penulis mengucapkan terima kasih kepada koordinator penelitian Adi Purwandana, M.Si serta peneliti dan teknisi Pusat Penelitian Oseanografi LIPI sehingga penelitian ini dapat terlaksana dengan baik.

\section{Daftar Pustaka}

Best, M. A. 2007. Dissolved oxygen as a physicochemical supporting element in the Water Framework Directive. Marine Pollution Bulletin 55:53-64.

Cardona, Y., A. Bracco, T. A. Villareal, A. Subramaniam, S. C. Weber, and J. P. Montoya. 2016. Highly variable nutrient concentrations in the Northern Gulf of Mexico. Deep Sea Research II 129:20-30.

Chen, C.-T. \& A. 2011. Nutrient Cycling in the
Oceans. Encyclopedia of Life Support System (EOLSS) 1:13 pp.

Hutagalung, H.P., A. Rozak dan I. Lutan. 1985. Beberapa Catatan Tentang Penentuan Kadar Oksigen dalam Air Laut Menggunakan Metode Winkler. Oseana X (4): 138-149.

Kementerian Lingkungan Hidup Republik Indonesia. 2004. Baku Mutu Air Laut untuk biota laut. Dalam: Keputusan Menteri Negara Lingkungan Hidup No.51 Tahun 2004 Tentang Baku Mutu Air Laut. KLH. Jakarta:32 hal

Koch-Larrouy, A., G. Madec, B. Blanke, and R. Molcard. 2008. Water mass transformation along the Indonesian throughflow in an OGCM. Ocean Dynamics 58 (3): 289-309.

Li, H. M., C. S. Zhang, X. R. Han, and X. Y. Shi. 2015. Changes in concentrations of oxygen, dissolved nitrogen, phosphate, and silicate in the southern Yellow Sea, 1980-2012: Sources and seaward gradients. Estuarine, Coastal and Shelf Science 163:44-55.

Liu, S. M., R. H. Li, G. L. Zhang, D. R. Wang, J. Z. Du, L. S. Herbeck, J. Zhang, and J. L. Ren. 2011. The impact of anthropogenic activities on nutrient dynamics in the tropical Wenchanghe and Wenjiaohe Estuary and Lagoon system in East Hainan, China. Marine Chemistry 125:49-68.

Liu, S. M., J. Zhang, H. T. Chen, and G. S. Zhang. 2005. Factors influencing nutrient dynamics in the eutrophic. Progress in Oceanography 66:66-85.

Merta, I. G. S., B. Iskandar, and S. Bahar. 2004. Musim Penangkapan Ikan di Indonesia, 2nd edition. Balai Riset Perikanan laut, BRKP DKP, Jakarta.

Millero, F. J., and M. L. Sohn. 1992. Chemical oceanography. p. CRC Press Inc. Boca Ruton. Ann Arbor. USA.

Najid, A., J. I. Pariwono, D. G. Bengen, S. Nurhakim, and A. S. Atmadipoera. 2012. Pola Musiman dan Antar Tahunan Salinitas Permukaan Laut di Perairan Utara JawaMadura. Maspari Journal 4(2):168-177.

Pasaribu, B. P., D. Manurung, and D. Nugroho. 2004. Fish Stock Assessment using Marine Acoustics Detection and Oceanographical Characteristic in Java Sea. Gayana 68(2):1-5.

Pasqueron de Fommervault, O., C. Migon, F. D'Ortenzio, M. Ribera d'Alcalà, and L. Coppola. 2015. Temporal variability of nutrient concentrations in the northwestern Mediterranean sea (DYFAMED time-series station). Deep-Sea Research I 100:1-12.

Pramuwardani, I., Hartono, Sunarto, and A. Sopaheluwakan. 2018. Indonesian rainfall 
variability during Western North Pacific and Australian monsoon phase related to convectively coupled equatorial waves. Arabian Journal of Geosciences 11 (21): 673.

Risko, A S Atmadipoera, I Jaya and E H Sudjono. 2016. Analysis of turbulent mixing in Dewakang Sill, Southern Makassar Strait. IOP conf Publishing.

Sachoemar, S. I., and T. Yanagi. 2001. Seasonal variation of water characteristics in the northern coastal area of Java. La mer 39:7785.

Susilo, E., F. Islamy, A. J. Saputra, J. J. Hidayat, A. R. Zaky, and K. I. Suniada. 2015. Pengaruh Dinamika Oseanografi Terhadap Hasil Tangkapan Ikan Pelagis PPN Kejawanan dari Data Satelit Oseanografi. Seminar Nasional Perikanan dan Kelautan V. Universitas Brawijaya.

Suthers, I., L. Bowling, T. Kobayashi, and D. Rissik. 2009. Sampling methods for plankton. In: Suthers, I. M. and D. Rissik (eds). Plankton: A Guide to Their Ecology and Monitoring for Water Quality. CSIRO Publishing. Australia.

UNEP. 2007. Approaches to the Assessment of Eutrophication in Mediteranian Coastal Waters.
USEPA. 2001. Technical Guidance Manual Estuarine and Coastal. Washington.

Wei, Q. S., Z. G. Yu, B. D. Wang, M. Z. Fu, C. S. Xia, L. Liu, R. F. Ge, H. W. Wang, and R. Zhan. 2016. Coupling of the spatial-temporal distributions of nutrients and physical conditions in the southern Yellow Sea. Journal of Marine Systems 156:30-45.

Wei, Q., Q. Yao, B. Wang, H. Wang, and Z. Yu. 2015. Long-term variation of nutrients in the southern Yellow Sea. Continental Shelf Research 111:184-196.

Wyrtki, K. 1961. Physical oceanography of Southeast Asian waters. Naga Report 2. Scripps Institution of Oceanography, La Jolla, CA.

Zang, C., S. Huang, M. Wu, S. Du, M. Scholz, F. Gao, C. Lin, Y. Guo, and Y. Dong. 2011. Comparison of Relationships Between $\mathrm{pH}$, Dissolved Oxygen and Chlorophyll a for Aquaculture and Non-aquaculture Waters. Water Air Soil Pollut 219:157-174.

Zhang, J., and X. Gao. 2016. Nutrient distribution and structure affect the acidification of eutrophic ocean margins: A case study in southwestern coast of the Laizhou Bay, China. Marine Pollution Bulletin 111:295-304. 